neofilolog

\author{
Czasopismo Polskiego Towarzystwa Neofilologicznego \\ ISSN 1429-2173, eISSN 2545-3971, 2020, NR 54/2, 245-268 \\ http://dx.doi.org/10.14746/n.2020.54.2.4 \\ http://poltowneo.org/
}

\author{
Anna Jaroszewska \\ Uniwersytet Warszawski \\ https://orcid.org/0000-0003-2788-593X \\ a.jaroszewska@uw.edu.pl
}

\title{
STUDIUM PRZYPADKU W BADANIACH GLOTTODYDAKTYCZNYCH
}

\begin{abstract}
Case Study in Language Teaching Studies
The presented article is an attempt at providing a systematic outline of the basic information on the case study in the context of using in the language teaching studies. Surely, it is not discovering any new knowledge. It is rather a discussion of some obvious issues which especially young researchers frequently remain unconscious of. Simultaneously, it is aimed at provoking thinking on the topic, followed by popularising this highly interesting and valuable method as it enables to study any human activity, both the mental one and the one related to social relations, on many planes. Obviously, provided specific conditions are met.
\end{abstract}

Keywords: language teaching, study methodology, case study

Słowa kluczowe: nauczanie języka, metodologia badań, studium przypadku

1. Człowiek (=uczący się): istota indywidualna, społeczna, wciąż zmienna i tajemnicza

Człowiek jest niewątpliwie istotą społeczną. Jego złożoność jako obiektu poznania wynika wprost z dychotomii działań, które podejmuje w wymiarze indywidualnym oraz międzyludzkim. Z jednej strony cechuje go podmiotowa sprawczość, która nie pozostaje bez znaczenia dla otoczenia, z drugiej - podatność na to, co robią inni oraz okoliczności, w których przyszło mu funkcjonować. 
Gruntowne rozpoznanie ludzkich potrzeb i możliwości, także w sferze edukacji, wymusza więc na współczesnych badaczach-humanistach dopełnienie warunku informacyjnej komplementarności. Ma to oczywisty związek z właściwym doborem metodologii badań. Bo choć wspólna biblioteka wiedzy o naszym gatunku wydaje się dziś znacznie bogatsza niż było to jeszcze sto, dwieście, trzysta lat temu i wcześniej, w osobliwych galaktykach ludzkich neuronów oraz genów wciąż poruszamy się po omacku, bardziej domniemając, aniżeli rozumiejąc - to w najlepszym wypadku. Na ile skutecznie i z pożytkiem dla nas i otaczającego nas świata z zasobów tej wiedzy potrafimy korzystać? Czas pokaże, czy jesteśmy mądrzejsi od swoich przodków, czy tylko wiemy od nich nieco więcej. Niezależnie od oceny tego potencjału, tajemnica ludzkiej egzystencji, w tym komunikacji interpersonalnej i społecznej (w głębszym tego słowa znaczeniu), jest stopniowo przez nas odkrywana. Cywilizacyjny postęp przejawiający się w szeroko pojętych zmianach kulturowych, przewartościowaniu relacji międzyludzkich, przyroście wiedzy i rozwoju technologii, przesądza zaś o tym, iż proces poznawania pozostaje - wbrew pozorom - nadal trudny. Wynika to m.in. ze skomplikowania ludzkiego życia, któremu towarzyszy wzmagający się efekt informacyjnej eksplozji, a jednocześnie niestabilność pozyskiwanych z otoczenia informacji ${ }^{1}$. $Z$ tego powodu za normę uznaje się dziś rozkwit wąskich specjalizacji, co nie wyklucza utrzymania lub nawet intensyfikacji interdyscyplinarności niektórych dyscyplin naukowych i wykorzystywanych na ich potrzeby metod badawczych. Dotyczy to m.in. dyscypliny nazywanej w Polsce glottodydaktyką i badań realizowanych w jej obszarze. Musi więc dotyczyć również uczestników tych badań; niezależnie od pełnionych przez nich ról, pochodzenia, wieku, stanu zdrowia, posiadania, charakteru czy poziomu kompetencji ogólnych i typowo komunikacyjnych. Jedne i drugie zresztą okazują się równie ważne na drodze do osiągania zarówno dobrostanu jednostki, jak i społecznej równowagi. Zrozumienie tych kwestii jest kluczowe na etapie projektowania badań naukowych, które w centrum zainteresowania stawiają właśnie człowieka i jego społeczną aktywność, a ściślej rzecz ujmując - uczącego się języków obcych w zmiennym środowisku kształcenia.

Dokonując pewnego uproszczenia, co wynika z ograniczeń objętościowych dla niniejszego tekstu, warto wobec powyższego zaakcentować na wstępie szereg cech ludzkich, których - jako badacze - musimy być świadomi i z którymi powinniśmy się liczyć, podejmując trud poznawczy na polu glottodydaktyki. Pamiętajmy zatem, że człowiek (=uczący się) to:

- istota żywa, myśląca i odczuwająca,

- psychofizyczna osobliwość,

${ }^{1}$ Zob. np.: Wilczyńska, Mackiewicz, Krajka (2019). 
- aktywny podmiot w otoczeniu społecznym,

- (mimo)wolny uczestnik interakcji międzyludzkich,

- nadawca i odbiorca w procesach komunikowania,

- dawca i jednoczesny biorca kulturowych wartości,

- naśladowca i/lub (współ)twórca,

- dysponent indywidualnych potrzeb i możliwości,

- interlokutor nie zawsze gotów uznać potrzeby innych, czasem potrzeb tych nieświadomy,

- przedstawiciel gatunku, który jest predysponowany do odkrywania, poznawania, rozwiązywania problemów,

- zakorzeniona społecznie jednostka, ewoluująca przez własną działalność uczeniową oraz pod wpływem zmian cywilizacyjnych, w których uczestniczy.

Dotychczasowe ustalenia, poczynione choćby na gruncie badań psychologicznych, socjologicznych, pedagogicznych, etnograficznych czy językoznawczych, przekonują o szczególnej wadze tych właściwości zarówno w procesie uczenia się, skutkującego rozwojem i działaniem osobniczym jednostki, jak i w zakresie relacji społecznych, w szczególności tych, jakie łączą uczącego się (=podmiot badania) z nauczycielem i/lub badaczem.

\section{Szkoła. „Monolit” czy „górski strumien”"?}

Przesłanką do przyjęcia określonej metodologii badawczej winno być nie tylko rozpoznanie podmiotu badań, który przez swą gatunkową osobliwość wyróżnia się nawet w pozornie homogenicznej grupie, ale i ocena otoczenia, w jakim ów podmiot podejmuje interesujące badacza działania. Nauczanie/uczenie się języków obcych, jako główny problem badawczy glottodydaktyki ${ }^{2}$, obliguje swą specyfiką do koncentracji uwagi nie tylko na uczniu i nauczycielu czy innych uczestnikach interakcji uczeniowych, lecz również na szkole, będącej przecież podstawowym miejscem, w którym do nauczania i uczenia się dochodzi (Jaroszewska, 2014b). Szkoła, nie zawsze, choć bardzo często, staje się głównym obszarem badań glottodydaktycznych, przy czym badaniem nie w każdym przypadku jest objęta cała instytucja lub zespół placówek wyróżniających się np. specjalizacją, poziomem kształcenia, lokalizacją itd. Niekiedy projekt badawczy ogranicza się do poznania zespołu klasowego bądź szczególnej pod pewnymi względami grupy uczniów. Kwestie te zostaną omówione na dalszym etapie rozważań.

${ }^{2}$ Zob. np.: Wilczyńska, Michońska-Stadnik (2010); Jaroszewska (2014a); Gębal (2019). 
Dla uważnych obserwatorów przemian edukacyjnych, których doświadczamy w ostatnich latach w Polsce, odpowiedź na pytanie o obraz, status czy też kondycję polskiej szkoły prawdopodobnie nie będzie prosta. Czy należy ją wciąż traktować jako "monolit”, a więc instytucję skostniałą, szablonową, a przez to przewidywalną i łatwą do zbadania ${ }^{3}$, czy też raczej jako „górski strumień", budzący jednoznaczne skojarzenia z dynamiką, zmianą, rozwojem, ale i nieprzewidywalnością oraz pewnym ryzykiem (również dla badacza) ${ }^{4}$ ? Dostrzegając wyraźne zróżnicowanie w zakresie przedstawianych na ten temat analiz oraz ocen, które pojawiają się zarówno w dyskursie naukowym, jak i wśród nauczycieli, rodziców uczniów czy choćby w mediach, autorka nie opowiada się za żadną ze stron polemiki (może nawet sporu). Stoi na stanowisku, że, mimo systemowego umocowania, każda z placówek edukacyjnych stanowiących potencjalny obiekt badań glottodydaktyczych wymaga szczególnego podejścia badawczego. Bezrefleksyjne kalkowanie wcześniej wykorzystanych rozwiązań metodologicznych bądź rutyna w postępowaniu badawczym bez należytego rozpoznania środowiska kształcenia może okazać się zgubną praktyką, która z kolei negatywnie może wpłynąć na wiarygodność wyników badań, a nawet przesądzić o ich niepowodzeniu. Z pewnością szkoły dawno już utraciły status instytucji hermetycznych, odizolowanych od wpływów zewnętrznych. Rozgrywające się w nich procesy nie przebiegają dziś w próżni: w oderwaniu od państwowości, misji, idei pedagogicznych, otoczenia gospodarczego, infrastrukturalnego i społeczno-kulturowego, w końcu potencjału, jaki w mury szkolne wnoszą uczestnicy procesu edukacyjnego, zwłaszcza uczniowie i kadra szkolna. Pomimo tendencji do unifikacji i odgórnie narzuconych norm funkcjonowania wynikających z ustawy zasadniczej, prawa oświatowego oraz szeregu innych aktów wykonawczych bądź dyrektyw o charakterze międzynarodowym, należy uznać ich instytucjonalny fenomen, którego istotną cechą jest im tylko właściwa i wyjątkowa kultura organizacyjna ${ }^{5}$. Podejmując studium przypadku (tak jednostki, jak i instytucji), trzeba mieć tego świadomość. Zatem również (roz)poznanie kultury organizacyjnej szkoły jest kluczowe dla powodzenia projektu badawczego w zakresie nauczania/uczenia się języków obcych.

\section{Glottodydaktyka: nauka interdyscyplinarna i otwarta}

Waga powyższych twierdzeń wynika wprost ze sposobu rozumienia glottodydaktyki oraz postrzegania systemu glottodydaktycznego, w którego centrum znajduje

\footnotetext{
${ }^{3}$ Czy łączenie tych cech ze „szkołą tradycyjną" jest jeszcze uzasadnione?

${ }^{4}$ Czy przymioty niegdyś „,nowej szkoły” można już wpisać w nurt tradycyjnego kształcenia?

${ }^{5}$ Zob. np.: Polak (2007).
} 
się układ glottodydaktyczny. Odsyłając Czytelnika do wnikliwych opracowań tudzież autorskich propozycji na ten temat ${ }^{6}$, warto $w$ tym miejscu podsumować, że do prymarnych zadań glottodydaktyki, które realizowane są na poziomach teoretyczno-empirycznym oraz stosowanym, zalicza się obecnie:

- wyjaśnianie zawiłości procesów nauczania/uczenia się języków obcych w różnych grupach wiekowych uczniów i w różnych kontekstach kształcenia,

- ustalanie czynników istotnych z perspektywy kształcenia poszczególnych sprawności językowych,

- dostarczanie odpowiedzi na szereg pytań dotyczących m.in. tego, jak i z wykorzystaniem jakich metod, środków i strategii nauczać/uczyć się języków obcych i jak wzbudzić/utrzymać motywację do uczenia się, by z jednej strony podnieść efektywność tych procesów, z drugiej usprawnić użycie rozwijanej w ten sposób szeroko pojętej kompetencji komunikacyjnej uczących się,

- rozpoznanie potrzeb, możliwości oraz warunków w zakresie dystrybucji pozajęzykowego przekazu - programu wychowawczego i/lub kompensacyjnego, jak np. wdrażanie do autonomii w uczeniu się, zaspokajanie potrzeb wyższego rzędu (przynależności, uznania, samorealizacji), utrzymywanie bądź podnoszenie sprawności intelektualnej, propagowanie i kształtowanie pożądanych wartości i postaw, które z jednej strony służą rozwojowi jednostki, z drugiej - społeczeństwa (dotyczy to m.in. kształtowania kompetencji międzykulturowej uczących się).

Działalność ta ma z jednej strony prowadzić do weryfikacji dotychczasowych i formułowania nowych teorii i hipotez na temat szeroko pojętych procesów nauczania/uczenia się języków obcych, z drugiej - powinna zmierzać do organizowania czy też konstruowania i ewaluacji środowiska kształcenia i takich narzędzi jego wspomagania, dzięki którym możliwa będzie optymalizacja tych procesów.

Stanowisko glottodydaktyków jest przy tym w gruncie rzeczy zgodne co do tego, że na układ glottodydaktyczny, a więc w centralnym miejscu badawczych poszukiwań, teoretycznych ustaleń i praktycznych realizacji, oddziałują sprzężone i zmienne, jak się też okazuje, wcale niemałe siły: natury stricte ludzkiej, materialnej, prawnej, politycznej, ideologicznej itd. Ich dynamika, natężenie, pośredni bądź bezpośredni wpływ na ucznia i nauczyciela, bliska lub daleka dyslokacja względem układu, w końcu poziom ich utajenia bądź uświadomienia przez „aktorów sceny glottodydaktycznej” (również badaczy) nie mogą

${ }^{6}$ Zob. np.: Grucza (1978: 29-n.); Woźniewicz (1987: 88); Pfeiffer (2001: 21); Wilczyńska, Michońska-Stadnik (2010: 29-n.); Gębal (2013: 26); Dakowska (2014). 
więc być marginalizowane w procesie badawczym (podobnie zresztą, jak i na etapie kształcenia). Ich niedostrzeżenie lub zamierzone przemilczenie będzie błędem. Jak liczne i zróżnicowane są to siły pozwala oszacować choćby tylko pobieżna analiza polskiego systemu edukacji. Dzisiaj na każdym jego szczeblu ma miejsce nauczanie/uczenie się języków obcych. Dotyczy to dzieci, jak i uczących się dorosłych, do wieku senioralnego włącznie. Procesy te zachodzą w edukacji formalnej i pozaformalnej; istotną rolę odgrywa również sfera nieformalnego uczenia się. Tymczasem jeszcze dwadzieścia lat temu miejsce i znaczenie języków obcych w systemie tym było zupełnie inne. Inny był również status ucznia, inaczej też podchodziło się do problematyki zawodu nauczyciela języków obcych, do nauczycielskich uprawnień, obowiązków czy kompetencji, jakże inne były cele, środki i metody nauczania. Wszystko to wydatnie przekładało się na ograniczony program nauczania języków obcych w polskich szkołach, a w konsekwencji na dość wąski program badawczy glottodydaktyki. Ten jednak z roku na rok się rozrasta.

\begin{tabular}{|c|c|c|}
\hline $\begin{array}{r}\text { Dziedzina nauk humanistycznych } \\
\text { archeologia } \\
\text { filozofia } \\
\text { historia } \\
\text { jezzykoznawstwo } \\
\text { literaturoznawstwo } \\
\text { nauki o kulturze i religii } \\
\text { nauki o sztuce } \\
\text { Dziedzina nauk inżynieryjno-technicznych } \\
\text { architektura i urbanistyka } \\
\text { automatyka, elektronika i elektrotechnika } \\
\text { informatyka techniczna i telekomunikacja } \\
\text { inżynieria biomedyczna } \\
\text { inżynieria chemiczna } \\
\text { inżynieria lądowa i transport } \\
\text { inżynieria materiałowa } \\
\text { inżynieria mechaniczna } \\
\text { inżynieria środowiska, górnictwo i energetyka } \\
\text { Dziedzina nauk medycznych i nauk o zdrowiu } \\
\text { nauki farmaceutyczne } \\
\text { nauki medyczne } \\
\text { nauki o kulturze fizycznej } \\
\text { nauki o zdrowiu } \\
\text { Dziedzina nauk rolniczych } \\
\text { nauki leśne } \\
\text { rolnictwo i ogrodnictwo } \\
\text { zechnologia żywności i żywienia } \\
\text { weterynaria } \\
\text { zootechnika i rybactwo }\end{array}$ & $\begin{array}{c}\text { ? } \\
\text { ? ? } \\
\text { ? ? ? ? } \\
\text { ? ? ? } \\
\text { ? }\end{array}$ & $\begin{array}{l}\text { Dziedzina nauk spolecznych } \\
\text { ekonomia i finanse } \\
\text { geografia społeczno-ekonomiczna i gospodarka } \\
\text { przestrzenna } \\
\text { nauki o bezpieczeństwie } \\
\text { nauki o komunikacji społecznej i mediach } \\
\text { nauki o polityce i administracji } \\
\text { nauki o zarządzaniu i jakości } \\
\text { nauki prawne } \\
\text { nauki socjologiczne } \\
\text { pedagogika } \\
\text { prawo kanoniczne } \\
\text { psychologia } \\
\text { Dziedzina nauk ścisłych i przyrodniczych } \\
\text { astronomia } \\
\text { informatyka } \\
\text { matematyka } \\
\text { nauki biologiczne } \\
\text { nauki chemiczne } \\
\text { nauki fizyczne } \\
\text { nauki o Ziemi i środowisku } \\
\text { Dziedzina nauk teologicznych } \\
\text { nauki teologiczne } \\
\text { Dziedzina sztuki } \\
\text { sztuki filmowe i teatralne } \\
\text { sztuki muzyczne } \\
\text { sztuki plastyczne i konserwacja dzieł sztuki }\end{array}$ \\
\hline
\end{tabular}

Ryc. 1: Nieokreślony status glottodydaktyki i jej interdyscyplinarne powiqzania na gruncie nowej klasyfikacji dziedzin i dyscyplin. Opracowanie własne na podstawie rozporządzenia MNiSW (Dz.U. 2018 poz. 1818).

Trudno jednoznacznie określić, czy ów rodzajowy i jednocześnie jakościowy rozkwit sprzyja prowadzeniu badań glottodydaktycznych, czy też czyni 
je bardziej skomplikowanymi. Niewątpliwie jednak przesądza o ich rosnącym potencjale i społecznym znaczeniu glottodydaktyki. Niestety nie znajduje to odzwierciedlenia w najnowszej klasyfikacji dziedzin i dyscyplin ogłoszonej w Rozporzq̨dzeniu Ministra Nauki i Szkolnictwa Wyższego z dnia 20 września 2018 r. w sprawie dziedzin nauki i dyscyplin naukowych oraz dyscyplin artystycznych (Dz.U. 2018 poz. 1818), gdzie miejsca dla glottodydaktyki wciąż nie przewidziano (zob. Ryc. 1.).

Swoisty stan zawieszenia między bogatą paletą nauk humanistycznych a równie rozbudowanym wykazem nauk społecznych siłą rzeczy przynosi glottodydaktyce i reprezentującemu ją środowisku pewne straty. Równocześnie jednak rodzi korzyści. Zastrzegając, że kwestia ta będzie przedmiotem odrębnego opracowania, należy podkreślić, iż brak nadania wyższej rangi aktem normatywnym nie wyklucza glottodydaktyki z grona dyscyplin autonomicznych. Jej wyraźnie zarysowany przedmiot badań, aparat pojęciowy i metodologiczny, w końcu dotychczasowy dorobek teoretyczny i wykształcona w tym kierunku kadra - mimo postępującego rozwoju i związanych z tym przemian stanowią dziś solidny fundament dla przyszłych badań uprawianych w ramach glottodydaktyki właśnie, a nie innych dyscyplin pokrewnych ${ }^{7}$. Potencjał ten buduje równocześnie tożsamość glottodydaktyków, którzy zamiast kryć się w cieniu coraz śmielej manifestują swoją odrębność i dokonania. Nie przekreśla to oczywiście utrzymania przez glottodydaktykę statusu nauki interdyscyplinarnej i otwartej, co wynika z wciąż powiększającej się rozpiętości oraz niejednorodności pól badawczych rzeczonej dyscypliny. To z kolei przesądza o szerokim spektrum metod badawczych wykorzystywanych na jej potrzeby. Do katalogu tego zalicza się także studium przypadku.

\section{Studium przypadku - charakterystyka metody}

Uznanie znaczeniowej, przedmiotowej, terytorialnej oraz podmiotowej rozpiętości glottodydaktyki w kontekście projektowanych badań uwydatnia możliwości zastosowania studium przypadku, które jest metodą (lub strategią) na wskroś interdyscyplinarną. To dzięki niej możemy uzyskać postulowany na wstępie efekt komplementarności badań, skumulować wyniki pojedynczych epizodów badawczych, odkrywając możliwie pełny obraz podmiotu, grupy podmiotów, szeroko rozumianej instytucji, sieci instytucji czy występujących w ich obrębie zjawisk uchwycony z perspektywy interesujących nas zmiennych.

\footnotetext{
${ }^{7}$ Zob. Wilczyńska (2010).
} 


\subsection{Definicja}

Studium przypadku nazywane jest często "metodą indywidualnych przypadków”, „pojedynczych przypadków”, „analizą przypadków” lub „metodą kliniczną” (Łobocki, 2006: 304). W literaturze przedmiotu definiowane jest bardzo różnorodnie, co wynika z jednej strony z uniwersalności tej metody i jej powszechnego wykorzystywania w różnych dziedzinach i w różnych celach - a więc i konieczności dostosowania do konkretnych potrzeb, warunków, możliwości, nomenklatury czy standardów obowiązujących w granicach danej dyscypliny, z drugiej - z uwarunkowań historycznych oraz kulturowych, w jakich był i jest realizowany ten rodzaj badań. Nie bez znaczenia jest przy tym sposób etykietowania własnej działalności przez samych badaczy, jak również (przychylne vs krytyczne) opinie środowiska naukowego na ten temat (Stake, 2009: 623-624; Yin, 2015: 23-24). Niezależnie więc od tego, czy studium przypadku uznamy za „specyficzną procedurę badawczą, która zmierza do jednostkowej teorii zjawiska ogólnego" (Konarzewski, 2000: 79), „osobliwe podejście czy postępowanie badawcze, wykorzystujące inne metody i techniki badań" (Łobocki, 2006: 305), , ,jednocześnie proces badania i jego produkt w postaci szczegółowego, wieloaspektowego opisu” (Kubinowski, 2010: 172) czy też „rodzaj badania hybrydowego, wykorzystującego wiele technik zbierania i analizy danych" (Wilczyńska, Michońska-Stadnik, 2010: 154) itd., warto być świadomym rozbieżności poglądów nie tylko w zakresie definiowania, lecz także wdrażania tej metody do praktyki badawczej (Mizerek, 2017: 10-n.). Na tę niejednorodność i związane z tym problemy, zwłaszcza początkujących badaczy, zwraca uwagę Yin (2015: 4748), przedstawiając dwuczłonową definicję studium przypadku wypracowaną na podstawie własnej kilkudziesięcioletniej praktyki badawczej oraz towarzyszących jej studiów teoretycznych nad tym zagadnieniem. Podkreślając całościowy charakter metody (zdaniem autora uwzględnia ona logikę projektu badawczego, techniki gromadzenia danych oraz sposób ich analizy), Yin (2015: 48-49) stwierdza, że:

„1. Studium przypadku jest badaniem empirycznym, które

- zgłębia współczesne zjawisko („przypadek”) w kontekście rzeczywistości, zwłaszcza gdy

- granice między zjawiskiem a kontekstem nie są zupełnie oczywiste.

2. Studium przypadku:

- dotyczy technicznie rozpoznawalnej sytuacji, w której interesujących badacza zmiennych jest znacznie więcej niż punktów danych i dlatego

- czerpie dowody z wielu źródeł oraz potwierdza zbieżność danych metodą triangulacji,

- a podczas gromadzenia i analizy danych odwołuje się do sformułowanych wcześniej założeń teoretycznych". 
Podążając za wskazówkami Yin’a (2015: 49) - by dokonać pogłębionej interpretacji przedstawionej powyżej definicji - warto odnieść się do głównych cech metody. W pewnym sensie eksponuje je definicja ukuta przez Simons (2009: 21, za: Mizerek, 2017: 12), według której: „studium przypadku jest, uwzględniającą wiele perspektyw teoretycznych, pogłębioną eksploracją złożoności oraz unikatowości konkretnego projektu, polityki, instytucji programu lub systemu funkcjonującego w naturalnym kontekście „realnego życia” (real life). Jest strategią badawczą odwołującą się do danych empirycznych oraz dowodów naukowych gromadzonych z zastosowaniem wielu metod". Takie wyjaśnienie stanowi doskonały punkt wyjścia do dalszych rozważań na ten temat.

\subsection{Cechy, cele, rodzaje}

Przede wszystkich należy podkreślić, że studium przypadku może być realizowane tak w procedurach jakościowych, jak i ilościowych czy mieszanych, zatem przypisywanie mu wyłącznie jakościowej orientacji jest nieporozumieniem (Konecki, 2000: 126; Pilch, Bauman, 2010: 297; Yin, 2015: 51; Gajdzica, 2016: 64-65). Zdaniem Stake'a (2009: 623-n.) to nie pobudki metodologiczne implikują jego dobór, lecz właśnie zainteresowanie konkretnym przypadkiem i jego właściwości, a zatem również realne możliwości jego zbadania. Przypadek może być prosty lub złożony, pojedynczy lub zbiorowy, zawsze jednak z jakichś względów szczególny, wyjątkowy, niepowtarzalny, osadzony w naturalnym kontekście sytuacyjnym: historycznym, społecznym, kulturowym, ekonomicznym, politycznym, etycznym, estetycznym, który może mieć i najczęściej ma znaczenie badawcze. To właśnie zależność między swoistością przedmiotu badań (przypadku) a uwagą badacza inicjującą proces poznania odróżnia je od innych metod i strategii badawczych, takich jak badania etnograficzne, biograficzne, w działaniu (Mizerek, 2017: 13). Jest to w przekonaniu autorki granica nieostra, zarówno bowiem metodologia tych badań, jak i ich potencjalny przedmiot często są do siebie zbliżone.

Przypadkiem przykuwającym uwagę badacza może być: osoba, grupa osób, wspólnota, instytucja, jej część lub sieć jej podobnych, organizacja, system lub jego ogniwo, program, projekt, zjawisko, wydarzenie, relacje międzyludzkie czy nawet konkretna decyzja (Stake, 2009: 624; Kubinowski, 2010: 172; Yin, 2015: 66$)^{8}$. Osadzenie przypadku w realnym kontekście społeczno-kulturowym (w szerokim tego słowa znaczeniu) sprawia, że z zasady należy go traktować jako pewien układ funkcjonalny współzależnych od siebie czynników. Do zbadania

\footnotetext{
${ }^{8}$ Ciekawą klasyfikację w tym kontekście przedstawili Bogdan i Biklen (2003: 54-n., za: Kubinowski, 2010: 175-176). Autorzy wyróżnili historyczno-organizacyjne, obserwacyjne, rodzinne oraz komunalne studium przypadku.
} 
przypadku niezbędne jest więc precyzyjne ustalenie jego granic, jak to wynika bowiem z wcześniejszych rozważań, zwykle jest on częścią większej całości, której poznaniem niekoniecznie musimy być w danej chwili zainteresowani. W centrum uwagi znajduje się przecież ów przypadek, co wcale nie oznacza, że wiedza o nim będzie bezużyteczna na etapie studiowania innych przypadków bądź prowadzenia tzw. badań ogólnych czy przekrojowych i odwrotnie (Stake, 2009: 625).

Zasadniczym celem studium przypadku jest szczegółowy, możliwie wyczerpujący opis podmiotu/przedmiotu badań - opis wieloperspektywiczny i wnikliwy na tyle, by tę swoistość rozpoznać i wyjaśnić, być może porównać ją z innymi przypadkami, celem uchwycenia pewnych prawidłowości i zależności, bądź zrozumieć ją w perspektywie nakreślonych już koncepcji teoretycznych, które być może wymagają dopełnienia lub nawet redefinicji. W kontekście badań nad edukacją - a do tego nurtu można zaliczyć badania glottodydaktyczne - studia przypadku podejmuje się w celu analizy zwykle nienormatywnych zachowań, postaw i osobowości człowieka (ucznia, nauczyciela, rodzica itd.), jak również poznania wiążących się z tym zjawisk, procesów, kontekstów. Ustalenia poczynione w drodze tego typu badań mogą służyć usprawnieniu procesów kształcenia, działań psychoterapeutycznych czy wychowawczych (Guziuk, 2004: 225; Łobocki, 2006: 304; Karpińska-Szaj, 2010: 82). Nienormatywność podmiotu/przedmiotu badań nie oznacza przy tym wyłącznie dysfunkcji, zaburzeń, regresu, lecz równie dobrze może być wyrazem odstępstw od norm powszechnie uważanych za pozytywne i pożądane, jak choćby wyjątkowe postępy w uczeniu się, ponadprzeciętne osiągnięcia sportowe wobec ograniczeń fizycznych, wysoka sumienność i motywacja mimo odnoszonych niepowodzeń szkolnych czy stuprocentowa frekwencja uczniów.

Tytuł niniejszego artykułu jednoznacznie dookreśla przedmiot prowadzonych rozważań. Odpowiadając jednak na pytanie o funkcjonalność studium przypadku, warto zauważyć, że może być ona rozpatrywana z perspektywy nienaukowej: praktycznej i dydaktycznej ${ }^{9}$, oraz stricte naukowej. Nie jest to bez znaczenia, jeśli sens stosowania tej metody ma implikować np. glottodydaktyka, z sobie tylko właściwym katalogiem celów i potrzeb. A te manifestowane są przecież przez różne podmioty układu glottodydaktycznego oraz otaczającego ten układ systemu; nie tylko przez badaczy ${ }^{10}$. Podobnie jak ma to miejsce w przypadku innych dyscyplin, tak i w tym cele układają się co prawda w pewne kontinuum, lecz mogą mieć zarówno charakter autonomiczny (a przez to w jakimś stopniu ograniczać zakres studium, nadając mu

\footnotetext{
${ }^{9}$ Zob. np. Jendrych, Wiśniewska (2009); Gajewska, Sowa (2014: 196).

${ }^{10}$ Choć i ci mogą przecież z powodzeniem korzystać z praktycznego oraz dydaktycznego studium przypadku.
} 
wymiar praktyczny lub dydaktyczny), jak i być elementem/motorem działania kompleksowego (co jest raczej domeną nauki) (zob. Ryc. 2).

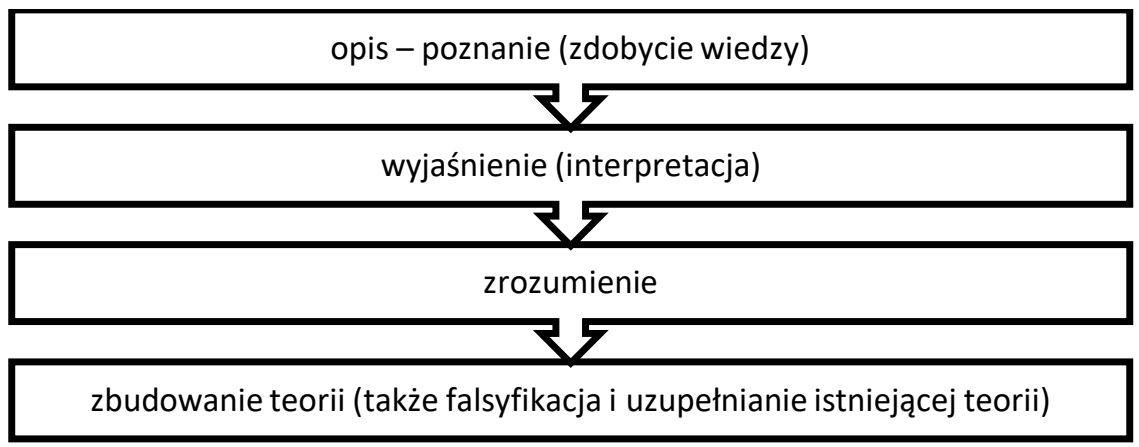

Ryc. 2: Cele studium przypadku. Źródło: Gajdzica (2016: 54) (własne opracowanie graficzne).

Jeśli zaś za twórców, ale i beneficjentów glottodydaktyki uznać nie tylko przedstawicieli środowiska naukowego, lecz również inne podmioty niezaangażowane bezpośrednio w proces budowania teorii glottodydaktycznych, w szczególności uczących się języków obcych i ich nauczycieli ${ }^{11}$, wówczas wartościowanie takiego czy innego studium (praktyczne vs dydaktyczne vs naukowe) jest bezcelowe. To kategorie nieporównywalne. O ich użyteczności i wadze przesądzają okoliczności oraz przede wszystkim odbiorcy czerpiący z nich informacje. Oczywiście można założyć, że naukowe studia przypadków są, a przynajmniej powinny być, metodologicznie uporządkowane, a dzięki temu dużo bardziej wyczerpujące i wiarygodne, co wynika z ogólnie przyjętych zasad pracy naukowej, w myśl których są realizowane (o tym dalej). Założenie to musi jednak znaleźć potwierdzenie w rzeczywistości, co nie zawsze ma miejsce. Poza tym naukowa diagnoza przypadku nie dla każdego z odbiorców będzie zrozumiała. Nie każdemu też będzie potrzebna. Mając to na uwadze, poniżej przedstawiono typologię studium przypadku, jakiej dokonał Mizerek (2017: 14) na podstawie wiodących konceptualizacji tego problemu w kontekście badań edukacyjnych (zob. Tabela 1 ) ${ }^{12}$. Zamieszczone $w$ tabeli 1 . odsyłacze źródłowe, jak również precyzyjne znaczeniowo nazwy nadane poszczególnym rodzajom

11 Działalność pierwszych bez drugich, a więc w oderwaniu od „realnego życia” i tak istotnej bazy empirycznej, byłaby po pierwsze niemożliwa, po drugie nie miałaby sensu. Jednocześnie powodzenie działalności drugich w dużej mierze uzależnione jest od dorobku tych pierwszych.

12 Zob. też: Konecki (2000: 127-n.); Kubinowski (2010: 173-n.); Matejun (2011: 95, za: Dondajewska, 2016: 44-45); Gajdzica (2016: 51-n.); Mizerek (2017: 13-n). 
studium, którymi posługują się kolejni autorzy, przesądziły o odstąpieniu w tym miejscu od szczegółowego komentarza na ten temat.

\begin{tabular}{|c|c|c|c|c|}
\hline $\begin{array}{c}\text { S. Merriam } \\
\text { (1988) }\end{array}$ & $\begin{array}{c}\text { R. Yin } \\
\text { (1994) }\end{array}$ & $\begin{array}{c}\text { R. Stake } \\
\text { (1995) }\end{array}$ & $\begin{array}{c}\text { M. Bassey } \\
\text { (1999) }\end{array}$ & $\begin{array}{c}\text { H. Simons } \\
\text { (2009) }\end{array}$ \\
\hline $\begin{array}{c}\text { opisowe } \\
\text { (ang. descriptive) }\end{array}$ & $\begin{array}{c}\text { wyjaśniające } \\
\text { (ang. explanatory) }\end{array}$ & $\begin{array}{c}\text { autoteliczne (istotne) } \\
\text { (ang. intrinsic) }\end{array}$ & $\begin{array}{c}\text { poszukujące teorii } \\
\text { (ang. theory-seeking) }\end{array}$ & $\begin{array}{c}\text { na podbudowie teorii } \\
\text { (ang. theory-led) }\end{array}$ \\
\hline $\begin{array}{c}\text { interpretatywne } \\
\text { (ang. interpretative) }\end{array}$ & $\begin{array}{c}\text { opisowe } \\
\text { (ang. descriptive) }\end{array}$ & $\begin{array}{c}\text { instrumentalne } \\
\text { (ang. instrumental) }\end{array}$ & $\begin{array}{c}\text { testujące teorie } \\
\text { (ang. theory-testing) }\end{array}$ & $\begin{array}{c}\text { generujące teorie } \\
\text { (ang. theory-generated) }\end{array}$ \\
\hline $\begin{array}{c}\text { ewaluatywne } \\
\text { (ang. evaluative) }\end{array}$ & $\begin{array}{c}\text { eksploracyjne } \\
\text { (ang. exploratory) }\end{array}$ & $\begin{array}{c}\text { zbiorowe (wielokrotne) } \\
\text { (ang. collective) }\end{array}$ & $\begin{array}{c}\text { narracyjne } \\
\text { (ang. story-telling) }\end{array}$ & $\begin{array}{c}\text { ewaluacyjne } \\
\text { (ang. evaluative) }\end{array}$ \\
\hline & & & $\begin{array}{c}\text { obrazujące } \\
\text { (ang. picture-drawing) }\end{array}$ & $\begin{array}{c}\text { etnograficzne } \\
\text { (ang. ethnographic) }\end{array}$ \\
\hline & & $\begin{array}{c}\text { ewaluacyjne } \\
\text { (ang. evaluative) }\end{array}$ & \\
\hline
\end{tabular}

Tabela 1: Typologia studium przypadku w badaniach edukacyjnych na podstawie analizy literatury przedmiotu. Źródło: Mizerek (2017: 14).

\subsection{Metody i zasady ich stosowania}

Z powyższego wynika, że studium przypadku może stanowić bardzo szeroką formułę postępowania badawczego, która przewiduje użycie wielu różnych metod, technik i narzędzi badawczych - zarówno na gruncie orientacji ilościowej, jak i jakościowej oraz mieszanej. O ich doborze i skali wykorzystania będą przesądzały przede wszystkim charakter przedmiotu/podmiotu, w tym otaczający go kontekst, jak również wyznaczone cele badań. W ramach studium przypadku najczęściej wykorzystywane są (Konecki, 2000: 132-133.; Łobocki, 2006: 305; Pilch, Bauman, 2010: 298; Yin, 2015: 132-133):

- obserwacja bezpośrednia, w tym obserwacja uczestnicząca;

- rozmowy i wywiady;

- analiza treściowa i formalna dokumentów osobistych, instytucjonalnych, prawnych i innych, w tym dokumentów archiwalnych;

- analiza wytworów własnych badanych osób, instytucji itd. oraz innych artefaktów fizycznych lub kulturowych mających z nimi związek;

- skale, testy, rep-testy psychologiczne;

- techniki projekcyjne.

Katalog ten warto dopełnić o dwie pozycje przemilczane w literaturze przedmiotu. Można je co prawda uznać za element składowy lub też wynikową powyższych działań badawczych, jednak rosnące możliwości zarówno w zakresie dostępu do tego typu informacji, jak i ich późniejszej analizy skłaniają autorkę, by je wyróżnić, akcentując tym samym ich wartość poznawczą. Są to: 
- analiza opinii dotyczących podmiotu/przedmiotu badań wydanych przez specjalistów;

- analiza dyskursu stanowiącego zarówno otoczenie, jak i wytwór podmiotu badań.

Pilch i Bauman (2010: 298-299) wskazują przy tym na kilka istotnych zasad, na których winien opierać się badacz, realizując studium przypadku. Są to:

- „zasada otwartości” - wyraża się w możliwie bliskich i szczerych relacjach między badającym i badanym; oznacza jednocześnie gotowość badacza na nowe i często nieprzewidziane sytuacje w procesie badawczym, które z kolei mogą implikować konieczność dostosowania lub zupełną zmianę metody badań;

- „zasada komunikacji” - ma służyć przede wszystkim podtrzymaniu możliwie długiej i pełnej relacji między badaczem a podmiotem badania, owocować dużą częstością spotkań, dzięki czemu zwielokrotniony zostaje dostęp badacza do interesujących go informacji; jest istotna również na etapie poznawania różnych kontekstów, w jakich znalazł się obiekt badań;

- „zasada naturalności” - oznacza prowadzenie badań w warunkach rzeczywistych, w środowisku naturalnym dla podmiotu/przedmiotu badań; badacz zostaje zobligowany do unikania sytuacji sztucznych, zaaranżowanych, w których właściwości badanego obiektu mogą zostać zaburzone, co negatywnie wpłynie na całościowy wynik badania;

- „zasada interpretacji” - zwraca uwagę na to, że dla powodzenia projektu badawczego ważny jest nie tylko gęsty opis przypadku, lecz również rzetelna interpretacja wszystkich danych zgromadzonych na jego temat.

W wykazie powyższym nie wymieniono zasad obiektywizmu, rzetelności, trafności oraz krytycyzmu ${ }^{13}$. Nie podkreślono też wagi zasad etycznych, którymi powinien kierować się każdy naukowiec, wkraczając w świat międzyludzkich relacji, uczuć czy norm prawnych. Wynika to prawdopodobnie nie tyle z przeoczenia autorów, ile raczej z założenia, że o tak oczywistych kryteriach pracy naukowej nie ma potrzeby wspominać. Doświadczenie piszącej te słowa pokazuje, że jednak warto. Warto też przywołać cztery zasady gromadzenia danych badawczych sformułowane przez Yin'a (2015: 150-161), który przekonuje do: 1) „korzystania z wielu źródeł dowodów”, mając na myśli triangulację danych, badaczy, teoretyczną i metodologiczną, 2) „tworzenia bazy danych studium przypadku", dotyczącej tak fazy organizacyjnej badań, jak i etapu

${ }^{13}$ Zob. np. Konarzewski (2000: 81). 
dokumentowania informacji zgromadzonych w toku studium, 3) „zachowania ciągłości łańcucha dowodowego", aby czytelnik studium niezaangażowany uprzednio w badanie mógł prześledzić kolejne kroki badacza, jednoznacznie identyfikując z nimi przedstawione w studium informacje, 4) „ostrożności w wykorzystywaniu danych ze źródeł elektronicznych", które wciąż jeszcze obarczone są niskim stopniem wiarygodności i konieczna okazuje się ich weryfikacja.

\subsection{Mocne i słabe strony}

Jak każdy rodzaj badań, tak i studium przypadku ma swoje słabe oraz mocne strony. Są ich świadomi zarówno zagorzali przeciwnicy tej metody, jak i jej zwolennicy. O ile jednak pierwsi, poddając ją krytyce, pozostają w dość komfortowej sytuacji, gdyż ich racje zwykle nie podlegają weryfikacji, to drudzy, podejmując trud studiowania przypadków, są na ogół rozliczani bardzo drobiazgowo z kolejnych kroków badawczych, zastosowanych procedur, pozyskanych danych i sposobu ich interpretacji. Jeśli zaś projekt badawczy realizowany jest $w$ ramach nie własnych, lecz zewnętrznych źródeł finansowania lub stanowi podstawę ubiegania się o awans naukowy, wówczas kontrola i ocena zdają się być jeszcze bardziej wnikliwe czy nawet surowe (nie oznacza to oczywiście, że badania realizowane innymi metodami takiej kontroli oraz ocenie nie podlegają). W literaturze przedmiotu kwestie te sygnalizowane są nader wyraźnie, zatem warto je przeanalizować jeszcze w fazie koncepcyjnej projektu badawczego, by wstępnie oszacować własny potencjał badawczy, by zawczasu przygotować się na niekiedy niemałe trudności ${ }^{14}$. Trafnego przeglądu zalet i wad studium przypadku dokonała np. Vissak (2010: 379, za: Dondajewska, 2016: 46). Pomimo że za perspektywę tego bilansu autorka przyjęła nauki o zarządzaniu, jest on na tyle uniwersalny, iż nawet jego dosłowne przytoczenie może okazać się użyteczne w świetle organizacji i prowadzenia badań glottodydaktycznych (zob. Tabela 2).

\subsection{Możliwości zastosowania w badaniach glottodydaktycznych}

Wielopłaszczyznowość i wielopodmiotowość obszaru badań glottodydaktycznych oraz niebagatelne znaczenie szeroko pojmowanego kontekstu, w jakim dochodzi do nauczania/uczenia się języków obcych, pozwala bez większych wątpliwości uznać przydatność metody studium przypadku również na gruncie glottodydaktyki ${ }^{15}$. $Z$ tej perspektywy indywidualnym przypadkiem może być zarówno pojedynczy uczeń, jak również grupa uczniów, nauczyciel lub nauczyciele,

14 Zob. np.: Łobocki (2006: 308n.); Yin (2015: 51-55, 248-249).

15 Zob. też Duff $(2008,2014)$. 
program szkolny czy szkoła itd. (zob. 4.2.). Koncentrując uwagę na podmiocie badania, warto podkreślić, że chodzi tu o osoby pośrednio bądź bezpośrednio zaangażowane w proces kształcenia obcojęzycznego, które w jakiś sposób wyróżniają się z grupy, wykraczają poza normę społeczną, stanowią swoistą enklawę na tle ogółu, a wyjaśnienie motywów i kierunków ich zachowań, postaw, schematów działania czy efektów pracy - innych, zaskakujących, problematycznych, niezgodnych z wcześniejszymi oczekiwaniami badacza lub po prostu rzadkich nie jest możliwe bez wnikliwego poznania zarówno ich samych, jak i okoliczności oraz miejsc, w których przyszło im funkcjonować: podejmować decyzje, osiągać ważne dla nich cele lub odnosić porażki. Przez okoliczności należy rozumieć dotychczasową biografię uczeniową oraz inne istotne doświadczenia życiowe - zarówno aktualne, jak i z przeszłości, otoczenie społeczne, w szczególności wpływ osób bliskich, warunki socjalne i ekonomiczne, uwarunkowania kulturowe, ideologiczne i prawne, zdarzenia krytyczne itd.

\begin{tabular}{|l|l|}
\hline \multicolumn{1}{|c|}{ Mocne strony } & \multicolumn{1}{c|}{ Słabe strony } \\
\hline - cieszą się popularnością w wielu dyscypli- & -są niedoceniane i rzadko wykorzystywane jako \\
nach naukowych & metoda badań naukowych \\
- mają wyższy response rate niż ankiety & -zarzuca się im niski stopień „naukowości” \\
- są przydatne do tworzenia nowej teorii & -spotyka je niska akceptowalność w prestiżo- \\
oraz krytyki lub uszczegółowiania istnieją- & wych czasopismach \\
cej teorii & -interpretacja wyników pozyskanych w ich trak- \\
- umożliwiają wyjaśnienie nowych, kom- & cie bywa trudna \\
pleksowych i dynamicznych aspektów & -są czaso- i pracochłonnne \\
działań organizacji & -są nieodpowiednie do badania dużych zbioro- \\
- są właściwe do uzyskania odpowiedzi na & wości \\
pytania jak? i dlaczego? dotyczące cyklu & -trudno na ich podstawie sformułować staty- \\
zdarzeń w organizacji & styczne uogólnienia \\
- umożliwiają holistyczne spojrzenie na wy- & -trudno w ich ramach pozyskać poufne dane \\
darzenia i procesy realizowane w ich rze- & w organizacjach - celowe zatajenie informacji \\
czywistym kontekście & przez uczestników badania \\
- umożliwiają jednoczesne prowadzenie & -ich wyniki mogą być obciążone stronniczością \\
badań jakościowych i ilościowych & i subiektywizmem badacza \\
- cechuje je duża elastyczność (wielość & -ich wyniki mogą być mało znaczące \\
sprzężeń zwrotnych) & \\
\hline
\end{tabular}

Tabela 2: Bilans mocnych i słabych stron studiów przypadku (Vissak, 2010: 379, za: Dondajewska, 2016: 46).

Studium przypadku warto stosować zatem wobec takich uczniów, którzy w konkretnej, realnej sytuacji uczenia się języka obcego przejawiają zaburzony, nieharmonijny rozwój lub - przeciwnie - osiągają nadzwyczaj spektakularne sukcesy w tym zakresie (Karpińska-Szaj, 2010: 82). Uwagę badacza mogą zwracać również nietypowe style pracy i współpracy czy strategie rozwiązywania 
problemów w uczeniu się, które - często wbrew logice - przynoszą pozytywne efekty lub mimo ich braku są bezrefleksyjnie kultywowane. Przesłanką do wdrożenia studium może być także szczególny charakter danej grupy uczniów lub palcówki oświatowej, gdzie występują nierozpoznane dotychczas relacje bądź procedury organizacyjne i dydaktyczno-wychowawcze. Ich wnikliwa eksploracja może prowadzić do ujawnienia pewnych braków natury systemowej (np. w zakresie regulacji prawnych, programu, metod i środków nauczania, źródeł finansowania zajęć pozalekcyjnych, współpracy partnerskiej z innymi instytucjami, diagnozy psychologiczno-pedagogicznej, działań terapeutycznych, działalności wychowawczej), jak i podmiotowej (np. w zakresie przygotowania psychopedagogicznego nauczycieli języków obcych, poziomu ich kierunkowego wykształcenia czy choćby postaw, udziału rodziców uczniów w procesie kształcenia, działalności wolontariuszy w murach szkolnych, włączenia uczniów w proces planowania i organizacji lekcji). Może też przyczynić się do uchwycenia przyczyn bądź rozwiązań dotychczas nieuwzględnianych w szkołach ogólnodostępnych czy w pracy z uczniami o określonym profilu charakterologicznym, istotnych z punktu widzenia poprawy warunków kształcenia obcojęzycznego oraz budowania nowych teorii na ten temat.

Kwerenda biblioteczna zawężona przez słowo klucz studium przypadku (ang. case study) powiązana z problematyką nauczania/uczenia się języków obcych ukazuje bogactwo badań zagranicznych oraz rodzimych, których autorzy podejmują bardzo zróżnicowane wątki badawcze ${ }^{16}$. Rozszerzenie spektrum zainteresowań poza uczniów uzdolnionych językowo lub obarczonych niepełnosprawnością czy deficytami nie powinno więc dziwić. Glottodydaktyczne studium przypadku może równie dobrze obejmować uczniów ze środowisk imigranckich czy rodzin wielokulturowych i wielojęzycznych, koncentrować się na uczniach, których rodzice są zatrudnieni w dyplomacji, ale też na uczniach z rozbitych małżeństw bądź z obszarów defaworyzowanych. Obiektem tego typu badań mogą stać się osoby lub grupy zawodowe uczące się języków specjalistycznych, a także uczniowie w wieku senioralnym. Studia przypadku kół zainteresowań, klas autorskich, eksperymentalnych, szkół alternatywnych, specjalnych, dyplomatycznych, katolickich, językowych, dwujęzycznych, wiejskich, przyszpitalnych, więziennych i zapewne wielu innych - a więc w jakimś stopniu niepowszechnych, ograniczonych podmiotowo, funkcjonalnie, ideowo, programowo, w końcu terytorialnie - mogą być przy tym podejmowane nie tylko ze względu na potrzebę/konieczność opisu, wyjaśnienia i oceny determinant aktywności oraz osiągnięć uczniowskich w zakresie rozwijania poszczególnych sprawności językowych czy kształtowania innych kompetencji

${ }^{16}$ Kilka przykładów przedstawiono w wykazie bibliograficznym. 
życiowych, istotnych dla uczenia się lub komunikacji. Ich celem może być także potrzeba poznania, zrozumienia, a niekiedy też usprawnienia założeń organizacyjno-metodycznych tego typu jednostek, które mogą jednocześnie stać się wzorem vs negatywnym przykładem dla innych. Również odbiegające od normy zachowania nauczycieli języków obcych, jako ważnego podmiotu układu glottodydaktycznego i głównego budowniczego środowiska kształcenia, ich przyczyny oraz skutki (np. zaburzone relacje z uczniem, nietrafne decyzje, autorski styl zarządzania klasą, zawodowa motywacja i demotywacja, ponadprzeciętna fluktuacja kadry, skargi, ale i pochwały składane przez uczniów/rodziców, niepowodzenia szkolne własnych uczniów) uzasadniają odwołanie się do studium przypadku, o ile dany przypadek właśnie rzeczywiście jest wyjątkowy i złożony, dotychczas nie rozpoznany, osadzony w szerszym kontekście, również historycznym.

Zogniskowanie uwagi na proces nauczania/uczenia się języków obcych nie wyklucza z kręgu zainteresowania badaczy przypadków także peryferyjnych ogniw systemu glottodydaktycznego ${ }^{17}$. Ich opis i eksplanacja - szczególnie z zamiarem podjęcia dalszych studiów porównawczych - może mieć niebagatelne znaczenie nie tylko dla efektywności funkcjonowania konkretnego układu glottodydaktycznego, lecz również w kontekście poszerzania zasobów wiedzy teoretycznej o układzie sensu largo. Dlatego w szczególnych wypadkach i nie zapominając o centralnym obiekcie zainteresowania glottodydaktyki, metodą studium przypadku możemy badać także całe systemy edukacyjne, uwzględniając nie tylko ich uwarunkowania historyczne i współczesne ramy prawne, polityczne oraz kulturowe, lecz również sposób zorganizowania oraz role działających w nich instytucji i organizacji, jak ministerstwo edukacji i kuratorium oświaty bądź ich odpowiedniki, placówki opieki przedszkolnej, wspomniane już szkoły, poradnie psychologiczno-pedagogiczne, ale też ośrodki akademickie zajmujące się kształceniem przyszłych nauczycieli języków obcych czy zaangażowane $w$ ten proces towarzystwa naukowe. One bowiem - współdziałając lub pozostając w dysharmonii - definiują ściśle określone warunki i sposoby kształcenia. Studium tego typu będzie jednak miało charakter przekrojowy, zaś za jego cel należy uznać uchwycenie funkcjonujących w danym systemie rozwiązań, epizodów bądź zjawisk, w jakiś sposób wyróżniających się spośród innych, innowacyjnych i/lub oryginalnych, z perspektywy teorii lub praktyki glottodydaktycznej ciekawych i przede wszystkim niezbadanych. Ich dostrzeżenie daje impuls do zainicjowania studium wtórnego, np. programów nauczania, wyrównywania szans, wymiany międzynarodowej, adaptacji kulturowej, wdrażania do autonomii, wielostronnej współpracy, profilaktyki

${ }^{17}$ Zob. Jaroszewska (2017). 
przeciwdziałania stereotypom i uprzedzeniom, mediacji, pomocy psychologiczno-pedagogicznej, resocjalizacji, praktyk zawodowych studentów i zawodowego doskonalenia nauczycieli itd. - by ukazać ich negatywną vs pozytywną stronę, by zgłębić ich właściwości. Jak się okazuje, mimo dynamicznego rozwoju glottodydaktyki czy innych kojarzonych z nią dyscyplin ${ }^{18}$, edukacyjna aktywność człowieka pozostaje wciąż nieograniczonym źródłem przypadków, które, czy to z przyczyn naukowych, czy praktycznych, warto badać.

\section{Podsumowanie}

Nauczanie/uczenie się języków obcych zmierza do rozwoju przez uczącego się kompetencji komunikacyjnej w danym obcym języku. Ta wyraża się - upraszczając - nie tylko w poznaniu obcego kodu językowego, lecz również w umiejętności jego użycia w naturalnym kontekście sytuacyjnym, z uwzględnieniem właściwych dla tego języka i posługującej się nim społeczności norm kulturowych. Co zrozumiałe, poziom czy też zakres tej kompetencji jest wartością indywidualną i zmienną (można odnotować zarówno jej przyrost, jak i ubytek), zaś proces jej rozwijania może zachodzić w warunkach nauki formalnej, pozaformalnej i nieformalnego uczenia się, a przy tym w różnym wieku życia uczącego się, co wydatnie rozszerza obszar badawczych poszukiwań w tym zakresie. Sprzężenie zwrotne, jakie występuje pomiędzy ogniwami systemu glottodydaktycznego - mentalnym, osobowym, materialnym - jak również znaczne rozmiary i dynamika tego systemu sprawiają, że wciąż dużo większym zainteresowaniem cieszy się wśród glottodydaktyków badanie łatwo mierzalnych właściwości znajdujących się w centrum układu glottodydaktycznego. Jego elementy/podmioty zdają się być w zasięgu wzroku. Zwłaszcza gdy zostają odseparowane od całości, od wielowątkowego kontekstu, jak choćby poszczególne sprawności językowe, które rozwijają i którymi posługują się uczniowie ze szkoły w najbliższym sąsiedztwie badacza lub takiej, gdzie znalazł on zatrudnienie. Zależności między poszczególnymi zmiennymi, które warunkują ich zaburzony, harmonijny lub szczególnie dynamiczny rozwój, można przecież ustalić nie angażując się w żmudny, a jednocześnie ograniczony cykl badawczy, obejmujący wiele kontekstów, lecz jeden bądź zaledwie kilka przypadków. Łączenie przyjemnego z pożytecznym jest wygodne i trudno się dziwić takiej tendencji. Przypadki szczególne, które kwalifikują się do studiów kompleksowych w swoim jednostkowym wymiarze, wciąż jeszcze zbyt często pozostają niezauważone lub są świadomie omijane $w$ fazie koncepcyjnej badań. Siłą rzeczy stanowią przecież reprezentację mniej liczną i zwykle trudniej dostępną względem

${ }^{18}$ Zob. Wilczyńska, Michońska-Stadnik (2010: 42-46). 
normatywnego ogółu. Dla wielu być może również mniej ważną aniżeli większość, pod potrzeby której wciąż jeszcze krojone są współczesne systemy edukacyjne - mimo szczytnych idei i wydawałoby się trafnych regulacji prawnych. Rzetelne zdiagnozowanie tych "trudnych" przypadków wymaga ubogacenia palety metod, technik i narzędzi badawczych. Wymaga jednocześnie umiejętności sprawnego nimi zarządzania w warunkach badań hybrydowych. Ponadprzeciętne kompetencje metodologiczne i społeczne, dyspozycyjność, gotowość do poniesienia większego nakładu sił i środków oraz wysoka motywacja do pracy naukowej stanowią rzadki konglomerat cech wśród młodych adeptów sztuki glottodydaktycznej, choć można oczywiście napotkać chlubne wyjątki od tej reguły. Zresztą, jak wielu jest badaczy starszej daty, którzy są gotowi na takie poświęcenie? Z jednej strony studiowanie przypadków daje nikłą nadzieję na uzyskanie spektakularnych wyników, w badaniach nad nimi nie występuje bowiem efekt skali, co z kolei bywa powodem umniejszania ich społecznego oraz stricte naukowego znaczenia, szczególnie w sytuacji, gdy zostają osadzone w paradygmacie jakościowym (Yin, 2015: 51-54). Z drugiej strony obranie tego kierunku w pracy naukowej może podważyć wiarygodność i dyscyplinarną przynależność badacza, gdy wykracza on poza "warowne mury" własnej dziedziny, co w przypadku badań glottodydaktycznych jest bardzo często koniecznością. Tymczasem metoda studium przypadku jest dziś tak samo naukowa, jak naukowo uzasadniona jest interdyscyplinarność umożliwiająca studiowanie problemów naukowych w zupełnie nowym i zdecydowanie szerszym kontekście (Kuc, 2012: 35-36). Czy zatem niemożność formułowania wielkich uogólnień powinna przesądzać o marginalizowaniu czy nawet piętnowaniu tak wartościowej metody? Wobec wyzwań współczesności i w myśl idei humanistycznych, które wciąż jeszcze wyznaczają kierunki rozwoju współczesnych społeczeństw demokratycznych i międzykulturowych, pozyskiwanie wiedzy o jednostce czy też grupach osób, instytucjach bądź zjawiskach rzadkich bądź niezrozumiałych, znajdujących się poza granicami normy społecznej, stanowi istotę nauki, podobnie jak badania wielkich populacji ${ }^{19}$. Pamiętając o niemniej ważnych nienaukowych celach studium przypadku, należy podkreślić za Stake'm (2009: 649), że to właśnie dzięki takim studiom możliwe staje się doprecyzowanie istniejących teorii. To one prowokują dalsze badania i wyznaczają granice tak pożądanej przez naukowców generalizacji. Autorka niniejszych rozważań stoi na stanowisku, że poznawania ich z czystej ludzkiej ciekawości również nie można nazwać błędem.

19 Zob. Strawiński (2011). 


\section{BIBLIOGRAFIA}

Bassey M. (1999), Case study research in educational settings. Buckingham Philadelphia: Open University Press.

Bogdan R.C., Biklen S.K. (2003), Qualitative Research of Education: An Introductive to Theories and Methods. Boston: Allyn and Bacon.

Dondajewska A. (2016), Studia przypadków w badaniach nauk o zarzqqdzaniu w świetle rygoru metodologicznego. „Zeszyty Naukowe Politechniki Poznańskiej. Organizacja i Zarządzanie", nr 70, s. 39-50.

Duff P.A. (2008), Case study research in applied linguistics. NY: Erlbaum/Taylor \& Francis.

Duff P.A. (2014), Case Study Research on Language Learning and Use. „Annual Review of Applied Linguistics", nr 34, s. 233-255.

Gajdzica Z. (2016), Uchwycić indywidualność, czyli o wybranych aspektach studium przypadku osoby z niepełnosprawnościq. „Interdyscyplinarne Konteksty Pedagogiki Specjalnej", nr 13, s. 49-66.

Gajewska E., Sowa M. (2014), LSP, FOS, Fachsprache... Dydaktyka języków specjalistycznych. Lublin: Wydawnictwo WERSET.

Gębal P.E. (2013), Modele kształcenia nauczycieli języków obcych w Polsce i w Niemczech. W stronę glottodydaktyki porównawczej. Kraków: Księgarnia Akademicka.

Gębal P.E. (2019), Dydaktyka języków obcych. Wprowadzenie. Warszawa: Wydawnictwo Naukowe PWN.

Grucza F. (1978), Glottodydaktyka, jej zakres i problemy. „Przegląd Glottodydaktyczny", nr 1, s. 29-44.

Guziuk M. (2004), Metody badań pedagogicznych, (w:) Pilch T. (red.), Encyklopedia pedagogiczna XXI wieku. t. III. Warszawa: Wydawnictwo Akademickie „Żak", s. 217-226.

Jaroszewska A. (2014a), O glottodydaktyce słowami glottodydaktyków. „Języki Obce w Szkole", nr 4, s. 52-66 Online: http://www.jows.pl/sites/def ault/files/wydania/JOwS_4_2014.pdf [DW 27.05.2020].

Jaroszewska A. (2014b), Budowanie przyjaznego środowiska wspierajqcego efektywnq naukę języków obcych. Poradnik nie tylko dla nauczycieli. Warszawa: Ośrodek Rozwoju Edukacji i Centrum Kształcenia Nauczycieli Języków Obcych i Edukacji Europejskiej Uniwersytetu Warszawskiego. Online: http://www.bc.ore.edu.pl/dlibra/docmetadata?id=590\&from=latest [DW 27.05.2020].

Jaroszewska A. (2017), Idea przyjaznego środowiska kształcenia na tle reformy polskiego systemu edukacji obcojęzycznej. "Studia Niemcoznawcze”, tom LIX, s. 569-581. 
Jendrych E., Wiśniewska H. (2009), Studium przypadku jako materiał dydaktyczny w nauczaniu specjalistycznego języka Business English. „Lingwistyka Stosowana. Przegląd", t. 1, s. 127-140.

Karpińska-Szaj K. (2010), Dialog w metodzie indywidualnych przypadków. „Neofilolog", nr 34, s. 81-90.

Konarzewski K. (2000), Jak uprawiać badania oświatowe. Metodologia praktyczna. Warszawa: Wydawnictwa Szkolne i Pedagogiczne.

Konecki K. (2000), Studia z metodologii badań jakościowych. Teoria ugruntowana. Warszawa: Wydawnictwo Naukowe PWN.

Kubinowski D. (2010), Jakościowe badania pedagogiczne. Filozofia - meto$d y k a-e w a l u a c j a$. Lublin: Wydawnictwo UMCS.

Kuc B.R. (2012), Funkcje nauki. Wstęp do metodologii. Nauka nie jest gra. Warszawa: Wydawnictwo PTM.

Łobocki M. (2006), Metody i techniki badań pedagogicznych. Kraków: Oficyna Wydawnicza "Impuls".

Matejun M. (2011), Metoda badania przypadków w naukach o zarzqdzaniu. „Ekonomika i Organizacja Przedsiębiorstwa”, nr 10, s. 93-102.

Merriam S.B. (1988). Case study research in education: A qualitative approach. San Francisco: Jossey-Bass.

Mizerek H. (2017), Studium przypadku w badaniach nad edukacjq. Istota i paleta zastosowań. „Przegląd Pedagogiczny” nr 1, s. 9-22.

Polak K. (2007), Kultura szkoły: od relacji społecznych do języka uczniowskiego. Kraków: Wydawnictwo Uniwersytetu Jagiellońskiego.

Rozporządzenie Ministra Nauki i Szkolnictwa Wyższego z dnia 20 września 2018 r. w sprawie dziedzin nauki i dyscyplin naukowych oraz dyscyplin artystycznych (Dz. U. 2018 poz. 1818).

Simons H. (2009). Case Study Research in Practice. London and New York: Sage Publications Inc.

Stake R.E. (1995). The Art of Case Study Research. Thousand Oaks: Sage Publications.

Stake R.E. (2009), Jakościowe studium przypadku , (w:) Denzin N.K., Lincoln Y.S. (red.), Metody badań jakościowych, t. 1. Warszawa: Wydawnictwo Naukowe PWN, s. 623-654.

Strawiński Z. (2011), Funkcja i cele nauki - zarys problematyki metodologicznej. „Zagadnienia naukoznawstwa”, nr 3 (189), s. 323-335.

Vissak T. (2010), Recommendations for Using the Case Study Method in International Business Research. „The Qualitative Report”, nr 15 (2), s. 370-388. Wilczyńska W. (2010), Obszary badawcze glottodydaktyki. „Neofilolog”, nr 34, s. 21-35.

Wilczyńska W., Mackiewicz M., Krajka J. (2019), Komunikacja interkulturowa. Wprowadzenie. Poznań: Wydawnictwo Naukowe UAM. 
Wilczyńska W., Michońska-Stadnik A. (2010), Metodologia badań w glottodydaktyce. Wprowadzenie. Kraków: Wydawnictwo AVALON.

Woźniewicz W. (1987), Kierowanie procesem glottodydaktycznym. Warszawa: PWN.

Yin R.K. (1994), Case study research: Design and methods. Beverly Hills: Sage Publications.

Yin R.K. (2015), Studium przypadku w badaniach naukowych. Projektowanie i metody. Kraków: Wydawnictwo Uniwersytetu Jagiellońskiego.

\section{Przykłady glottodydaktycznych studiów przypadków ${ }^{20}$}

Caldas S., Caron-Caldas S. (2000), The influence of family, school, and community on bilingual preference: Results from a Louisiana/Quebec case study. „Journal of Applied Psycholinguistics”, nr 21(3), s. 365-381.

Górczyńska E., Górska-Poręcka B. (2005), Nauczanie języków obcych przez Internet. Studium projektu, (w:) Mackiewicz M. (red.), Dydaktyka języków obcych a kompetencja kulturowa i komunikacja interkulturowa. Poznań: Wyższa Szkoła Bankowa, s. 357-364.

Han H. (2009), Institutionalized inclusion: A case study on support for immigrants in English learning. „TESOL Quarterly”, nr 43, s. 643-668.

Harklau L. (2008), Developing qualitative longitudinal case studies of advanced language learners, (w:) Ortega L., Byrnes H. (red.), The longitudinal study of advanced language capacities. New York: Routledge, s. 23-35.

Januszewska E., Markowska-Manista U. (2017), Dziecko „inne” kulturowo w Polsce. Z badań nad edukacjq szkolnq. Warszawa: Wydawnictwo Akademii Pedagogiki Specjalnej.

Jaroszewska A. (2012), W poszukiwaniu źródeł aktywności seniorów. Studium przypadku z pogranicza glottodydaktyki i geragogiki, „Orbis Linguarum", vol. 38, s. 571-595.

Jaroszewska A. (2013), Nauczanie języków obcych seniorów w Polsce. Analiza potrzeb i możliwości w aspekcie międzykulturowym. Kraków: Oficyna Wydawnicza „Impuls".

Jaworska M. (2009), Stopień autonomii uczq̨cych się a wpływ Europejskiego portfolio językowego na rozwój ich umiejętności autoewaluacji i postrzeganie przez nich pracy z tym narzędziem - studium indywidualnych przypadków, (w:) Pawlak M., Derenowski M., Wolski B. (red.), Problemy współczesnej dydaktyki języków obcych. Kalisz: Wydział PedagogicznoArtystyczny UAM w Kaliszu, s. 171-179.

\footnotetext{
${ }^{20} \mathrm{~W}$ wykazie nie uwzględniono bardzo licznych prac z zakresu logopedii i glottodydaktyki ojczystojęzycznej. Prace nie były poddane wnikliwej lekturze z kilkoma wyjątkami.
} 
Jaworska M. (2016), Indywidualny styl uczenia się a preferowane strategie - studium przypadku ucznia dyslektycznego. „Neofilolog”, nr 47/2, s. 231-242. Jaworska M. (2018), Nauczanie i uczenie się języków obcych młodzieży z dysleksjq. Kraków: Oficyna Wydawnicza „Impuls”.

Kinginger C. (2008), Language learning in study abroad: Case studies of Americans in France. "The Modern Language Journal”, nr 92, s. 1-124.

Kmiecik D., Siemdaj J. (2017), Dziecko obcojęzyczne w klasie szkolnej: studium przypadku, (w:) Duda A.K, Łukasik J.M. (red.), Polsko-rosyjskie kolaże: edukacja, społeczeństwo, kultura. Kraków: Uniwersytet Pedagogiczny im. Komisji Edukacji Narodowej, s. 73-90.

Koštálová-Perschke K. (2012), Mowa dwujęzycznej Julki - studium przypadku. Grin Verlag.

Kowalcze K. (2009), Bilingwizm w sytuacji komunikacyjnej wyrażania emocji. Studium przypadków dwujęzyczności polsko-włoskiej, (w:) Miodunka W.T. (red.), Nowa generacja w glottodydaktyce polonistycznej. Kraków: Wydawnictwo Universitas, s. 49-84.

Kuros-Kowalska K. (2015), Diagnoza poziomu słownika dziecka dwujęzycznego w języku prymarnym i sekundarnym: studium przypadku, (w:) Guzy A., Niesporek-Szamburska B., Wójcik-Dudek M. (red.), Szkoła bez barier: o trudnościach w nauczaniu i uczeniu się. Katowice: Wydawnictwa Uniwersytetu Śląskiego, s. 125-136.

Kyrc B. (2018), Dziecko dwujęzyczne jako uczeń o specjalnych potrzebach edukacyjnych. Słownik dziecka dwujęzycznego - studium przypadku. „Postscriptum Polonistyczne", nr 2 (22), s. 51-67.

Lardiere D. (2007), Ultimate attainment in second language acquisition: A case study. Mahwah, NJ: Erlbaum.

Levchuk P. (2015). Polska szkoła a cudzoziemcy. Studium przypadku dziecka z Ukrainy, (w:) Roter-Bourkane A., Kwiatkowska A. (red.), Horyzonty nauczania języka polskiego jako obcego. Poznań: TetraStudio Agencja Interaktywna, s. 61-70. Online: http://schoolpl.amu.edu.pl/upload/articles/galeria/ebooki/Horyzonty_nauczania.pdf [DW 27.05.2020].

Mikulska A. (2016), Rola środowiska pozaszkolnego w procesie akwizycji języka... polskiego przez dziecko cudzoziemskie - studium przypadku. „Annales Universitatis Pedagogicae Cracoviensis", t. 7, nr 223, s. 126-137.

Miodunka W., Dębski R. (red.) (2016), Bilingwizm polsko-obcy dziś. Od teorii i metodologii badań do studiów przypadków. Kraków: Księgarnia Akademicka.

Schmidt R., Frota S. (1986), Developing basic conversational ability in a second language: A case study of an adult learner of Portuguese, (w:) Day R. (red.), Talking to learn: Conversation in second language acquisition. Rowley, MA: Newbury House, s. 237-326. 
Stasiak S. (2019), Nienaturalna dwujęzyczność rodzinna. Studium przypadku chłopca ze spektrum autyzmu. „Języki Obce w Szkole”, nr 1, s. 43-47.

Tsui M., Amy B.M. (2003), Understanding expertise in teaching: case studies of second language teachers. Cambridge, New York: Cambridge University Press.

Wąsikiewicz-Firlej E. (2016), Język i tożsamość w rodzinie transnarodowej: studium przypadku. „Neofilolog”, nr 47/2, s. 153-169. 